\title{
SISTEM INFORMASI MANAJEMEN NURSERY ANGGREK DENGAN PENDEKATAN PENGEMBANGAN PERANGKAT LUNAK YANG HIJAU
}

\author{
${ }^{1}$ Luh Gede Surya Kartika, ${ }^{2}$ Komang Rinartha, ${ }^{3}$ Ni Luh Putri Srinadi \\ ${ }^{1,2}$ Sistem Komputer, STIKOM Bali, \\ Jln. Raya Puputan No. 86 Renon, Denpasar Timur. \\ ${ }^{3}$ Sistem Informasi, STIKOM Bali, \\ Jln. Raya Puputan No. 86 Renon, Denpasar Timur. \\ Email: ${ }^{1}$ Suryakartika1109@gmail.com, ${ }^{2}$ komangrinartha@ gmail.com, ${ }^{3}$ putri@ stikom-bali.ac.id
}

\begin{abstract}
ABSTRAK
Komputasi yang dilakukan dengan tidak bijak dapat menjadi salah satu faktor yang berperan langsung terhadap emisi gas rumah kaca yang berdampak pada pemanasan global. Teknologi informasi dan komunikasi dapat juga memberikan kontribusi signifikan dalam penghematan energi melalui optimalisasi efisiensi dari penggunanya dan mendorong perubahan sikap perilaku pengguna. Penelitian ini dilakukan pada usaha tanaman hias (nursery) anggrek di Denpasar. Hingga saat ini, usaha Nursery Anggrek mengalami perkembangan yang cukup signifkan. Penelitian ini berupaya menghasilkan sebuah Sistem Informasi Manajemen (SIM) Nursery Anggrek. Pendekatan yang digunakan dalam alur perekayasaan adalah mengadaptasi dari Green Software Development Life Cycle sesuai dengan GREENSOFT Model. Tujuan dari konsep pengembangan perangkat lunak yang hijau adalah menghasilkan sebuah perangkat lunak yang ketika digunakan tidak akan membutuhkan kinerja CPU yang besar, memerlukan bandwith dan memory yang kecil, serta ketika dipasang tidak berukuran besar. Dampak akhirnya adalah usaha Nursery Anggrek dapat melakukan perubahan proses bisnis agar efisiensi energi dapat maksimal. Penelitian ini merupakan tahap pertama dari dua tahap penelitian yaitu: pengembangan perangkat lunak dan evaluasi sistem. Tahap pertama terdiri dari kegiatan: (1) analisis kebutuhan; (2) perancangan dan pengkodean; dan (3) pengujian sistem. Hasil dari penelitian tahap pertama ini menghasilkan sebuah perangkat lunak dengan spesifikasi sesuai dengan kebutuhan Nursery Anggrek.
\end{abstract}

Kata Kunci: greensoft model, nursery anggrek, sistem informasi manajemen

\section{A. PENDAHULUAN}

Peningkatan jumlah perangkat dan aplikasi pada bidang teknologi informasi dan komunikasi (TIK) saat ini, menyebabkan meningkatkan dampaknya terhadap lingkungan karena sumber daya dan konsumsi dayanya. Apabila komputasi tersebut tidak dilakukan secara bijak maka dapat menjadi salah satu faktor yang berperan langsung emisi gas rumah kaca yang berdampak pada pemanasan global (global warming). Namun, TIK dapat juga memberikan kontribusi signifikan dalam penghematan energi, dengan upaya optimalisasi efisiensi dari penggunanya dan dengan mendorong perubahan sikap dan nilai perilaku pengguna TIK.

Keterkaitan teknologi informasi (TI) dalam kontek perubahan iklim adalah karena TI menggunakan energi yang cukup besar dalam opersionalnya. Sebagai ilustrasi energi listrik yang digunakan oleh sebuah perangkat komputer desktop (PC) menghabiskan $868 \mathrm{KW}$ per tahun. Jika satu perusahaan menggunakan 20.000 PC, energi yang digunakan setara dengan 12,467 metrik ton gas karbon dioksida (C02) [1]. Gas karbon dioksida tersebut setara dengan emisi gas dari 2.384 kendaraan, atau komsumsi bahan bakar 28.994 barel, atau pengunaan listrik 1.619 rumah tangga selama setahun. Contoh perhitungan tersebut hanya dari satu perusahaan dan hanya perangkat $\mathrm{PC}$, belum termasuk perangkat tambahan, misalnya pendingin ruangan (AC) dan lainnya.

Penelitian ini dilakukan pada usaha tanaman hias (nursery) anggrek di Denpasar. Hingga saat ini, usaha Nursery anggrek mengalami perkembangan yang cukup signifkan. Berdasarkan Badan Pusat Statistik tahun 2018, di Bali, produksi anggrek sebanyak 1190003 tangkai pada tahun 2014 dan terus meningkat tiap tahunnya. Bahkan jumlah tersebut menyumbang $6 \%$ dari keseluruhan produksi anggrek di Indonesia.

Jumlah produksi anggrek yang tidak sedikit menunjukkan bahwa kegiatan bisnis pada usaha tanaman hias anggrek di Bali relatif besar. Hasil observasi di lapangan menunjukkan bahwa, kegiatan bisnis pada usaha anggrek terdiri dari penyewaan dan jual beli secara retail maupun grosir. Kegiatan transaksi bisnis tersebut dapat dibantu dengan menggunakan sistem informasi manajemen. Transaksi bisnis yang relatif besar tersebut tentu berpengaruh langsung terhadap intensitas penggunaan perangkat lunak dan perangkat keras komputer.

Penelitian ini berupaya untuk 
Manajemen (SIM) Nursery anggrek dengan pendekatan pengembangan yang hijau. Salah satu target konsep pengembangan perangkat lunak yang hijau, adalah menghasilkan sebuah perangkat lunak yang ketika digunakan tidak akan membutuhkan kinerja CPU yang besar, memerlukan bandwith dan memory yang kecil, serta ketika dipasang tidak berukuran besar [2]. Dampak akhirnya adalah usaha Nursery Anggrek dapat melakukan perubahan proses bisnis sekaligus melakukan efisiensi energi pada sisi penggunaan perangkat lunak.

\section{B. LANDASAN TEORI}

Berbagai penelitian mengenai TIK yang hijau berfokus pada kelestarian lingkungan dalam hal perangkat keras komputer. Mengungkapkan masalah yang terkait dengan konsumsi energi dalam perangkat lunak dapat sangat membantu dalam mencapai komputasi hijau. Fitur perangkat lunak bertanggung jawab terhadap emisi CO2 sama seperti komponen perangkat keras. Perangkat lunak memiliki efek tidak langsung terhadap lingkungan dengan mengoperasikan dan mengelola perangkat keras yang mendasarinya. Hingga saat ini, telah dikembangkan perangkat lunak yang dapat melakukan pemantauan dan memanfaatkan sumber daya secara efisien, atau perangkat lunak yang bersifat berkelanjutan sehingga membatasi kebutuhan penambahan perangkat keras karena pembaruan.

Penelitian mengenai green software development atau pengembangan perangkat lunak yang hijau telah menjadi isu yang menarik. Penelitian dibidang ini telah dilakukan oleh beberapa peneliti sebelumnya, seperti yang ditunjukkan oleh Tabel 1.
Tabel 1. Hasil dari penelitian sejenis oleh peneliti pendahulu

\begin{tabular}{|c|c|c|}
\hline No & $\begin{array}{c}\text { Peneliti } \\
\text { dan topik }\end{array}$ & Hasil yang dicapai \\
\hline 1 & [3] & $\begin{array}{l}\text { Artikel ini menyajikan panduan checklist } \\
\text { dan pendekatan peduli lingkungan } \\
\text { dimulai dari langkah paling awal dalam } \\
\text { menemukan kebutuhan pengguna (user } \\
\text { requirements). Elaborasi tersebut } \\
\text { digambarkan melalui studi kasus pada } \\
\text { car sharing system. }\end{array}$ \\
\hline 2 & [4] & $\begin{array}{l}\text { Artikel ini bertujuan untuk } \\
\text { mengeksplorasi korelasi antara kualitas } \\
\text { perangkat lunak dan efisiensi energi. }\end{array}$ \\
\hline 3 & [5] & $\begin{array}{l}\text { Dalam artikel ini disajikan pendekatan } \\
\text { untuk menganalisis jejak karbon } \\
\text { perangkat lunak. }\end{array}$ \\
\hline 4 & [6] & $\begin{array}{l}\text { Memberikan rujukan model untuk } \\
\text { perangkat lunak yang hijau, serta } \\
\text { penggunannya. }\end{array}$ \\
\hline
\end{tabular}

Penelitian yang telah dilakukan oleh peneliti pendahulu sebagian besar mengenai cara atau model pengembangan perangkat lunak yang hijau. Hingga saat ini belum ditemukan hasil penelitian mengenai perangkat lunak yang dihasilkan dari model-model tersebut atau hasil evaluasi real dari sebuah perangkat lunak yang diklaim bersifat green.

\section{B.1. GREENSOFT Model}

Penelitian ini mengadaptasi model GREENSOFT. Model tersebut (Gambar 1) mencakup model siklus hidup holistik untuk produk perangkat lunak, kriteria keberlanjutan dan metrik untuk produk perangkat lunak, model proses untuk berbagai pemangku kepentingan serta rekomendasi dan alat yang mendukung pemangku kepentingan saat mengembangkan, mengadakan, mempertahankan dan menggunakan produk perangkat lunak di cara yang kompatibel dengan tujuan pembangunan berkelanjutan.

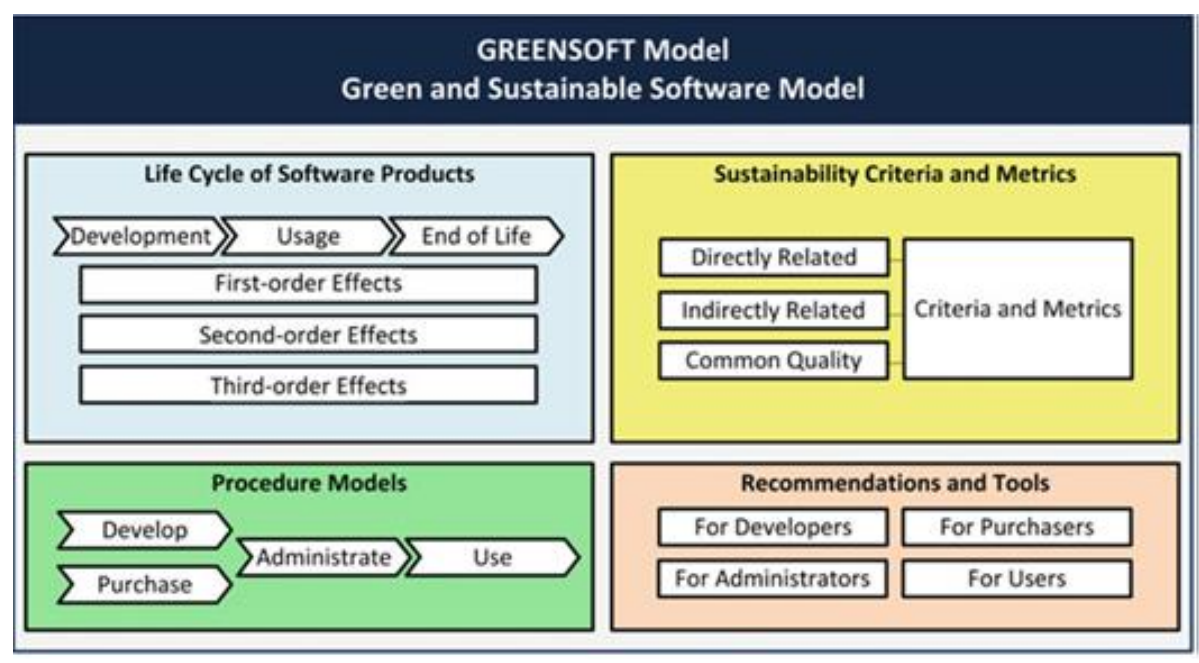

Gambar 1. Model GREENSOFT [7]

Tujuan dari Model GREENSOFT adalah untuk menilai kompatibilitas ekonomi, manusia, sosial dan ekologi sebuah produk perangkat lunak selama siklus hidupnya. Model tersebut juga 
memberikan kriteria dan metrik keberlanjutan mencakup metrik umum dan kriteria untuk pengukuran kualitas perangkat lunak. Model ini juga memungkinkan klasifikasi proses yang mendukung pengadaan, pengembangan, administrasi dan penggunaan perangkat lunak dalam konteks pengembangan berkelanjutan.

Bagian terakhir dari model ini menunjukkan rekomendasi untuk tindakan dan alat pengembangan perangkat lunak. Bagian tersebut memberikan panduan kepada para pemangku kepentingan dalam penerapan teknik untuk mempromosikan tujuan berkelanjutan (sustainable purpose). Tingkat pengetahuan dan pengalaman para aktor yang berbeda harus dipertimbangkan. Aktor di bidang ini adalah pengembang perangkat lunak, pembeli, administrator serta profesional dan pengguna pribadi tetapi juga semua yang terlibat dalam produk perangkat lunak secara umum..

\section{B.2. Perangkat Lunak Berkelanjutan}

Dalam [3], dikatakan bahwa "Perangkat Lunak Berkelanjutan" dapat diartikan dalam dua cara:

(1) kode perangkat lunak yang berkelanjutan, agnostik tujuan; atau

(2) tujuan perangkat lunak untuk mendukung tujuan keberlanjutan.
Oleh karena itu, dalam penelitian ini, perangkat lunak berkelanjutan adalah hemat energi, meminimalkan dampak lingkungan dari proses yang didukungnya, dan memiliki dampak positif pada keberlanjutan sosial dan/atau ekonomi. Dampak ini dapat terjadi langsung (energi) dan tidak langsung (dikurangi oleh penggunaan) atau sebagai efek rebound'. Perangkat lunak berkelanjutan adalah perangkat lunak, yang berdampak pada ekonomi, masyarakat, manusia, dan lingkungan yang dihasilkan dari pengembangan, penyebaran, dan penggunaan perangkat lunak yang minimal dan/atau yang memiliki efek positif pada pembangunan berkelanjutan

\section{B.3. Emisi Karbon dari Produk TIK}

Sektor TIK berkontribusi sekitar 2\% dari emisi $\mathrm{CO} 2$ global dan bertanggung jawab untuk sekitar $8 \%$ penggunaan listrik di Eropa, dan sekitar $2 \%$ emisi karbon berasal dari sektor peralatan dan layanan TIK dan elektronik rumah tangga. Konsumsi listrik total sektor TIK diperkirakan akan meningkat hampir 60\% dari 2007 hingga 2020 (Gambar 2.2) karena meningkatnya jumlah perangkat serta perluasan jaringan [8].

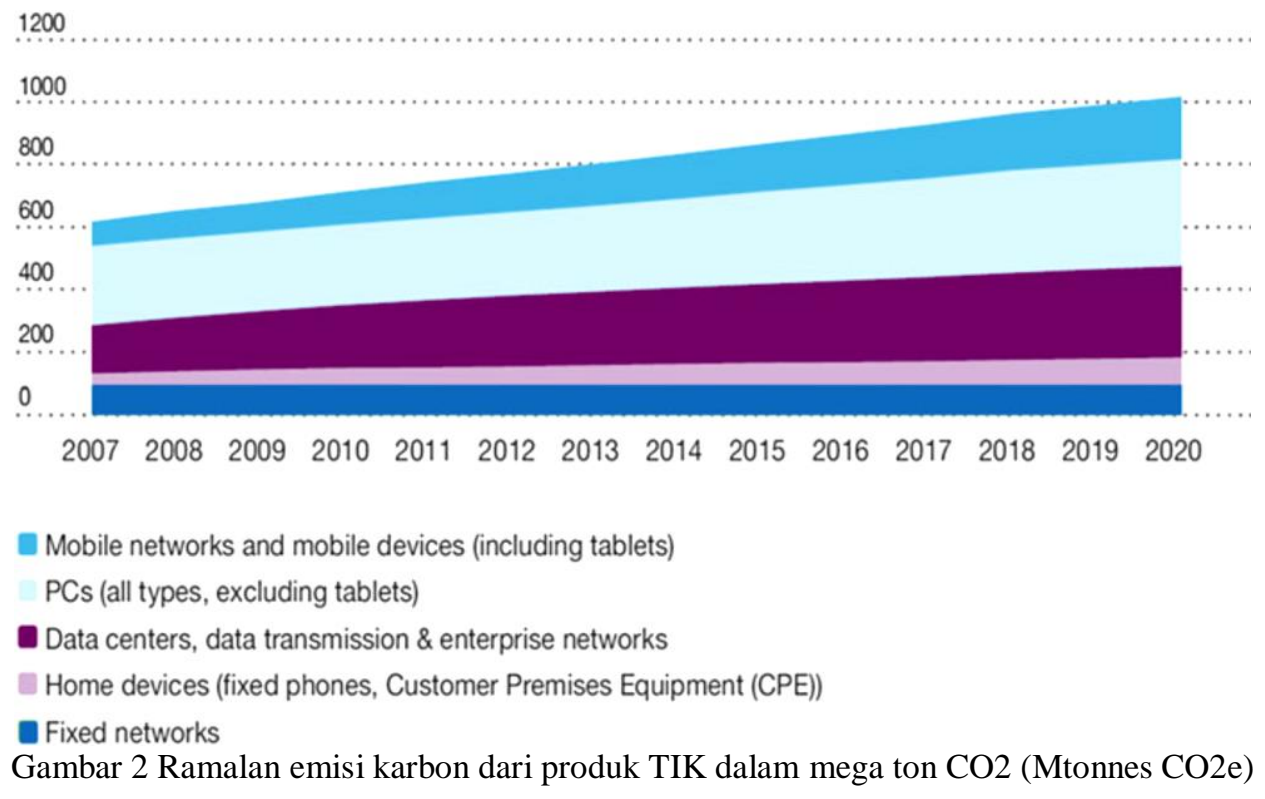

\section{METODOLOGI PENELITIAN}

Penelitian dilaksanakan pada Nursery Anggrek di Kota Denpasar. Penelitian dilaksanakan selama lima bulan dimulai dari bulan Agustus 2018 hingga Desember 2018. Nursery Anggrek dipilih sebagai objek penelitian sebab, industry tanaman hias saat ini telah berkembang pesat di Bali. Pengambilan data dan studi kasus dilaksanakan pada Duta Orchid.

Penelitian ini terbagi menjadi dua bagian yaitu pengembangan perangkat lunak dan evaluasi sistem, kedua hal tersebut dijabarkan dalam alur perekayasaan Gambar 3. Artikel ini membahas bagian pertama yaitu pengembangan perangkat lunak.

\section{C.1. Analisis Kebutuhan}

Analisis kebutuhan dilakukan untuk mengetahui kebutuhan dari pengguna SIM Nursery anggrek. Studi kasus dalam penelitian ini adalah Nursery anggrek Duta Orchid Denpasar. Kebutuhan pengguna yang akan dikumpulkan 
dimulai dari kebutuhan fungsional hingga kebutuhan non fungsional. Kebutuhan fungsional dari sistem akan dikumpulkan melalui metode wawancara dan observasi. Kebutuhan non fungsional digali dengan panduan dari [3], yaitu dengan pertanyaan mendasar sebagai berikut:

(1) Apakah sistem tersebut memiliki tujuan kelestarian yang bersifat eksplisit?
(2) Apakah dampak utama dari sistem terhadap lingkungan?

(3) Apakah terdapat pemangku kepentingan dari kelestarian lingkungan?

(4) Apakah tujuan dan hambatan utama dari sistem dalam tujuannya menjaga kelestarian lingkungan?

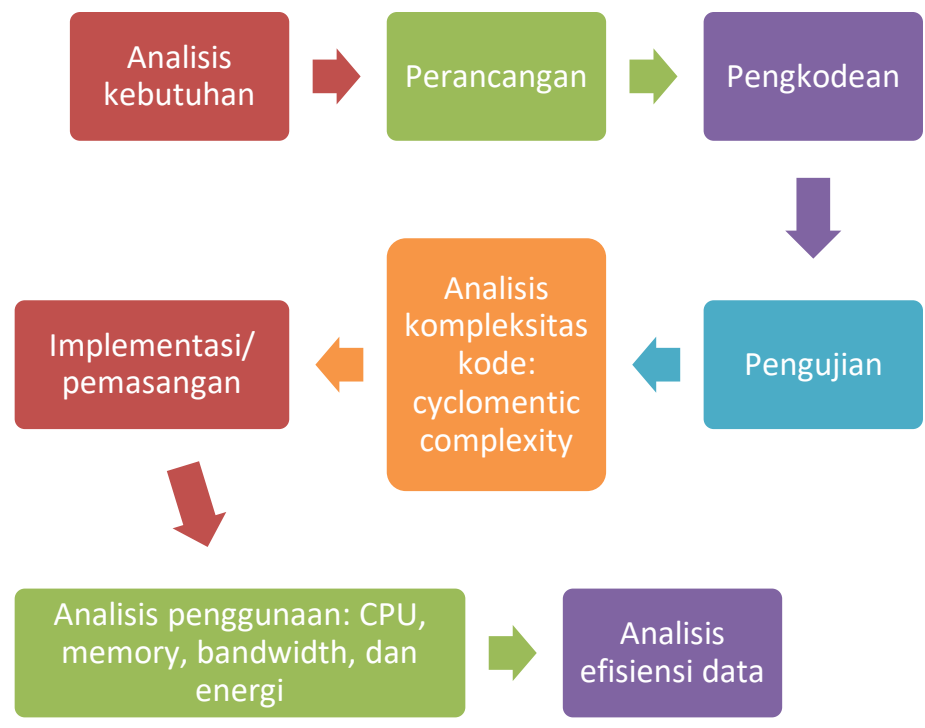

Gambar 3. Alur perekayasan

\section{C.2. Perancangan dan Pengkodean}

Hasil analisis kebutuhan digunakan untuk membuat rancangan SIM Nursery Angrek. Rancangan yang akan dibuat adalah:

(1) Rancangan data menggunakan Entity Relationship Diagram

(2) Rancangan prosedural menggunakan Data Flow Diagram.

Pengkodean dilakukan berdasarkan rancangan yang telah dibuat. Proses pengkodean mengadopsi prinsip-prinsip pengkodean yang disampaikan oleh [9]:

(1) Programmer harus menulis algoritma yang efisien melalui penulisan desain kode dan struktur data yang ringkas berdasarkan aplikasi, bahasa pemrograman, dan arsitektur perangkat keras.

(2) Efek dari penggunaan kembali (reuse) dan penggunaan framework, serta library merugikan dalam hal efisiensi energi. Lapisan-lapisan tambahan tersebut membutuhkan kerja ekstra dari prosesor ketika kode program eksekusi.

(3) Bahasa pemrograman yang digunakan untuk pengkodean adalah PHP dengan DBMS MySQL.

\section{C.3. Pengujian}

Dalam penelitian ini proses pengujian menekankan pada menemukan ketidaksesuaian dengan kebutuhan pengguna serta menemukan kesalahan atau cacat dalam SIM Nursery Anggrek. Pengujian dilakukan dalam tiga tahapan yaitu: pengujian unit, dan pengujian sistem (volume testing).

\section{C.4. Analisis Cyclometic Complexity}

Analisis dilakukan dengan dua teknik, yaitu whitebox dan blackbox. Whitebox dilakukan dengan berbasis path untuk menemukan cyclometic complexity sistem, atau tingkat kompleksitas kode program dalam sistem. Sedangkan, blackbox dilakukan berbasis interface untuk menemukan kesalahan, ketidaksesuaian dengan kebutuhan pengguna, dan software defect (kecacatan).

\section{C.5. Analisis Penggunaan CPU, memory, energi, dan bandwidth}

Analisis penggunaan CPU, memory, dan bandwidth merupakan bagian dari hasil pengujian efisiensi perangkat lunak dalam konteks kelestarian lingkungan [2][10]. 


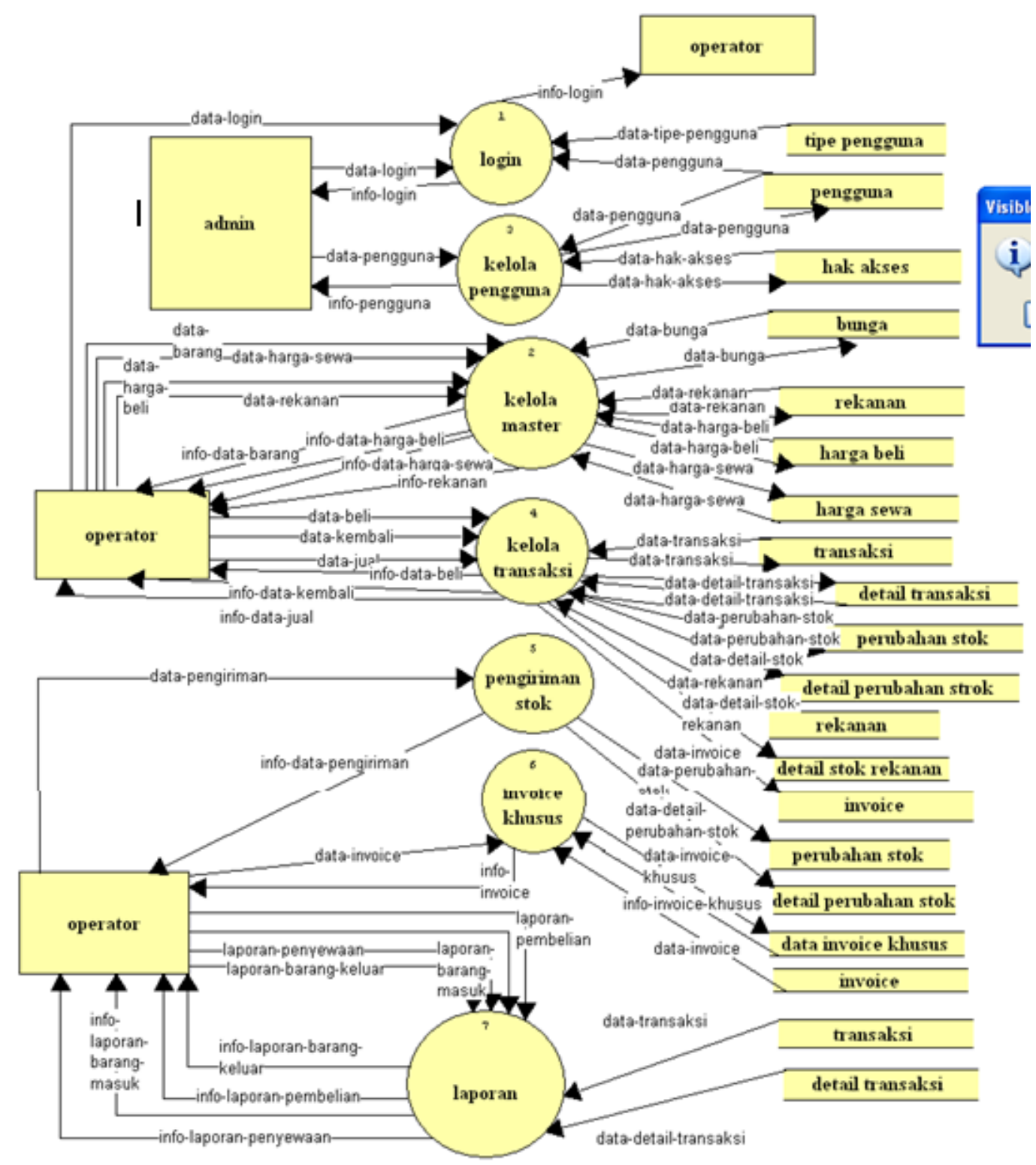

Gambar 4. Data flow diagram level 0 sistem Nursery Anggrek

\section{ANALISIS DAN PERANCANGAN}

\section{D.1. Analisis Kebutuhan Pengguna}

Hasil dari wawancara pada studi kasus Duta Orchid menunjukkan bahwa Nursery Anggrek memiliki kebutuhan fungsional sebagai berikut:

(1) Sistem mampu menyimpan dan mengolah informasi transaksi penyewaan dan pengembalian bunga

(2) Sistem mampu mampu menyimpan dan mengolah informasi transaksi penerimaan stok bunga, baik dari kebun bunga maupun dari supplier bunga lainnya.

(3) Sistem mampu menyimpan dan mengolah informasi transaksi penjualan bunga secara retail maupun partai besar.

(4) Sistem mampu menyedikan laporan transaksi yang terjadi dalam bentuk grafik dengan periode pelaporan tertentu. Laporan yang dibutuhkan adalah minimal: laporan transaksi sewa, penjualan, barang masuk (stok), dan barang keluar.

(5) Pengguna sistem perlu untuk login terlebih dahulu dengan hak akses yang berbeda tergantung dari tugas dan jabatan pengguna tersebut.

(6) Sistem dapat mencetak invoice yang akan digunakan untuk pengantar dalam pengiriman bunga kepada penyewa bunga.

(7) Sistem mampu menyimpan dan mengolah informasi piutang dari proses penyewaan.

(8) Harga sewa dan harga jual bunga terhadap masing-masing pelanggan dapat berbeda sesuai dengan kebutuhan dan kontrak penyewaan.

Kebutuhan non fungsional dari sistem adalah sebagai berikut: 
(1) Sistem tidak memiliki tujuan yang berkaitan langsung dengan pelestarian lingkungan, namun penghematan energi selama penggunaan sistem merupakan hal yang penting dan dibutuhkan

(2) Sistem dapat diakses dimana saja dan kapan saja (accessible).

(3) Sistem mudah digunakan (userfriendly).

\section{D.2. Perancangan Sistem}

Berdasarkan hasil analisis kebutuhan, maka sistem yang dibangun memiliki tujuh unit utama yang ditunjukkan melalui Data Flow Diagram Level 0 Gambar 4. Gambar 5 menunjukkan rancangan Entity Relationship Diagram.

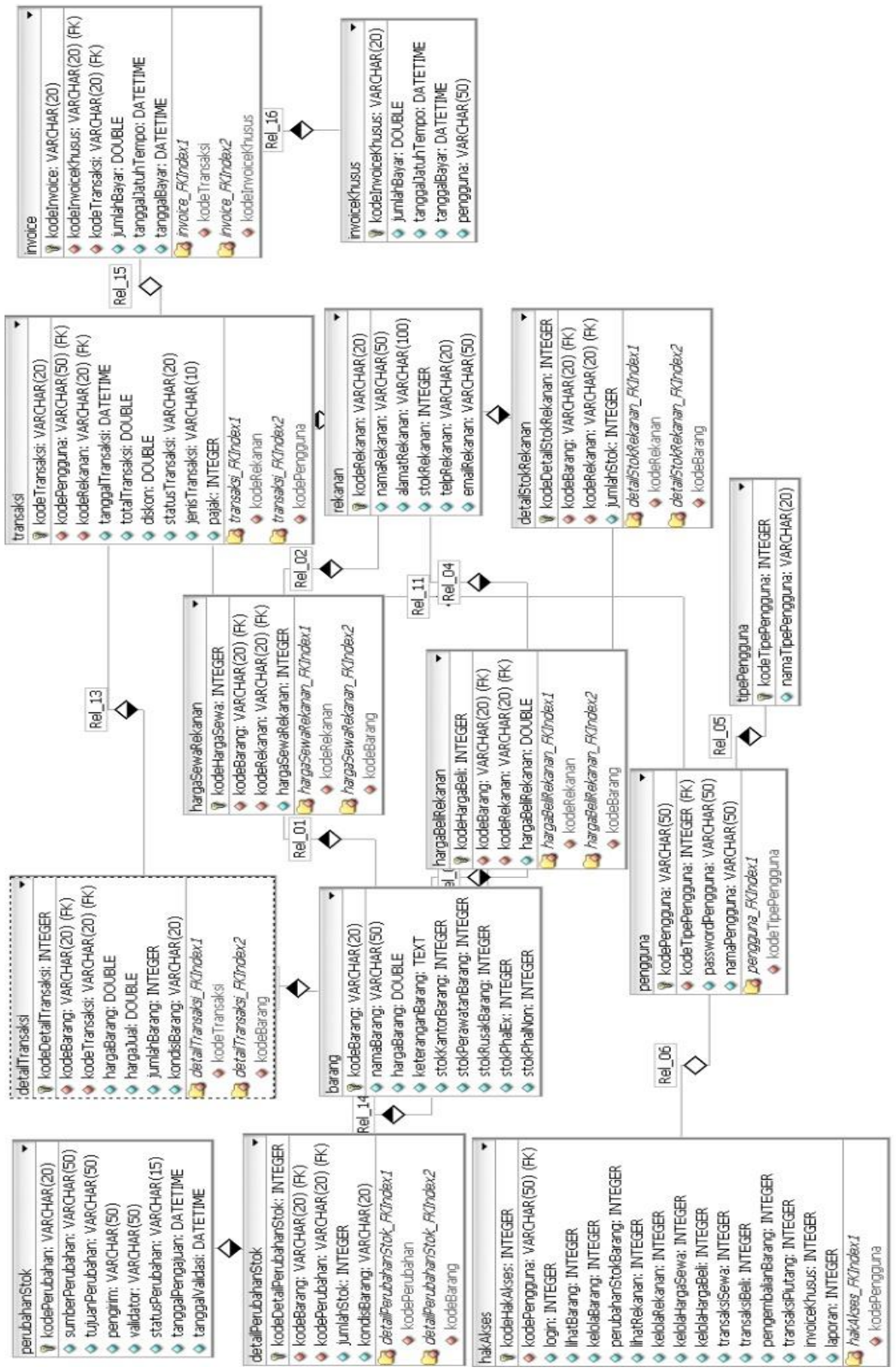

Gambar 5. Rancangan entity relationship diagram 
Jurnal Ilmiah Rekayasa dan Manajemen Sistem Informasi, Vol. 4, No. 2, Agustus 2018, Hal. 183-193 e-ISSN 2502-8995, p-ISSN 2460-8181

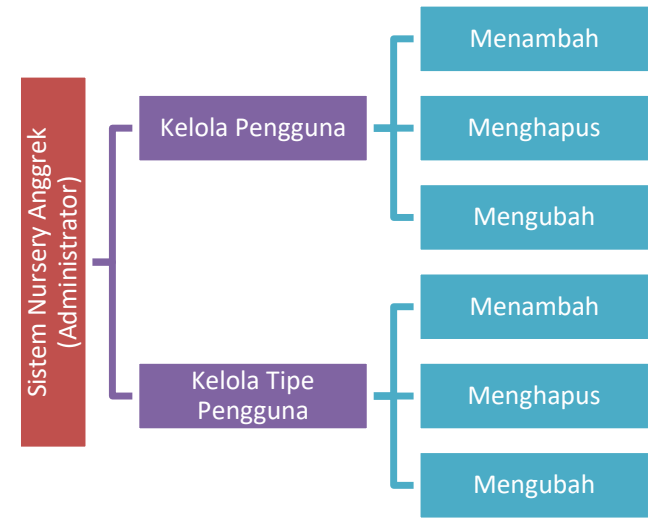

Gambar 6. Struktur menu sistem backend untuk administrator

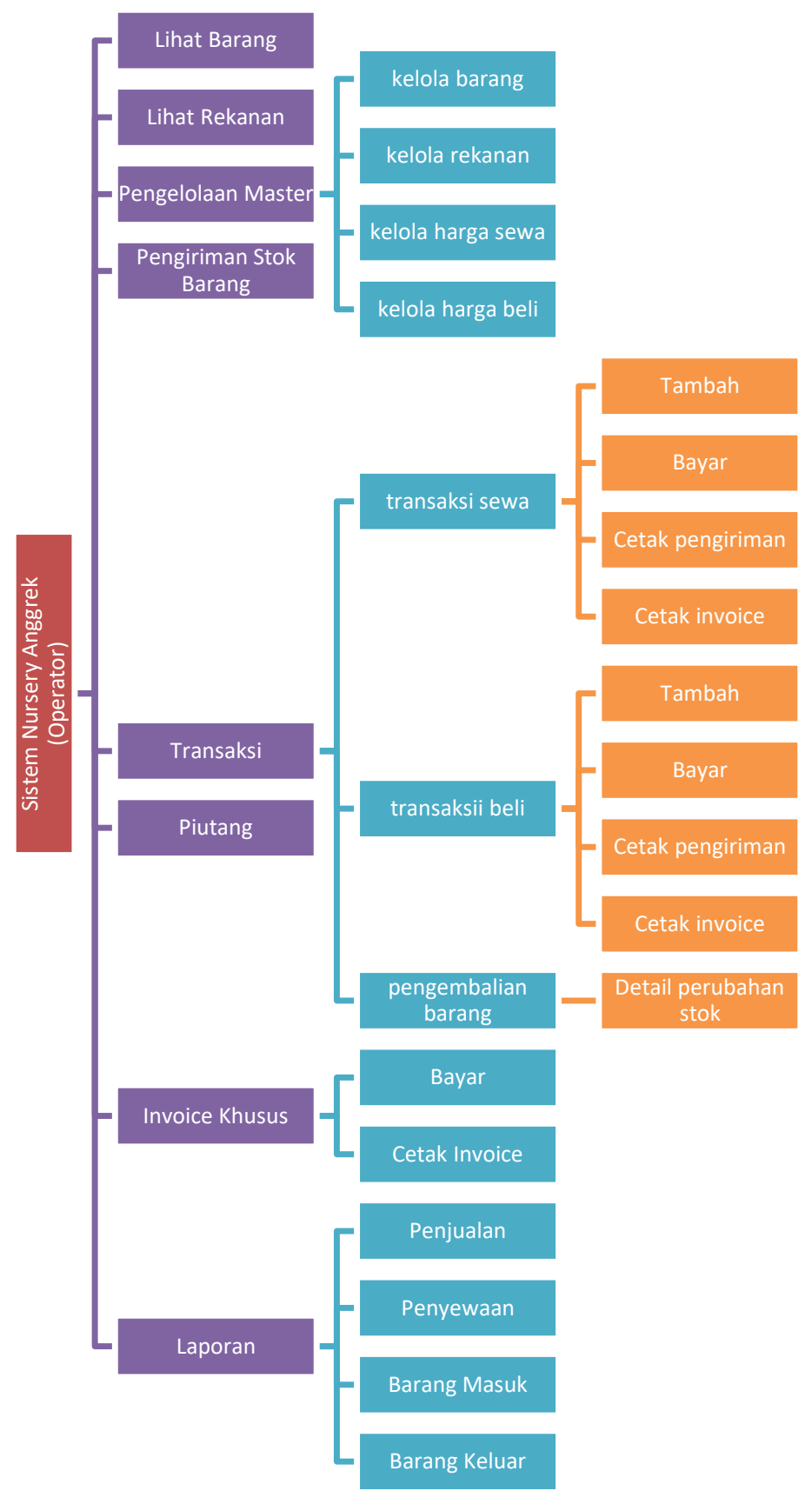

Gambar 7. Struktur menu aplikasi Nursery Anggrek untuk operator 
Gambar 6 menunjukkan struktur menu sistem backend untuk administrator. Gambar 7 menunjukkan struktur menu aplikasi Nursery Anggrek untuk operator.

\section{E. HASIL IMPLEMENTASI DAN PENGUJIAN}

Berdasarkan hasil perancangan, maka sistem Nursery Anggrek memiliki 39 halaman yaitu: halaman login, halaman ubah profile, menu kelola tipe pengguna, menu pengelolaan pengguna, menu tambah pengguna, menu edit pengguna, menu lihat barang, menu lihat rekanan, menu pengelolaan master, menu kelola barang, menu kelola rekanan, menu kelola harga sewa, menu kelola harga beli, menu pengiriman stok barang, menu tambah pengiriman barang, menu detail pengiriman barang, menu tambah pengiriman barang, cetak surat kirim barang, tampilan validasi pengiriman, menu transaksi, menu transaksi sewa, menu transaksi beli, menu transaksi pengembalian, menu tambah transaksi sewa, detail transaksi sewa, menu tambah transaksi beli, detail transaksi beli, menu pengembalian barang, menu tambah pengembalian barang, detail pengembalian barang, menu validasi pengembalian barang, menu piutang, menu invoice khusus, detail menu invoice khusus, menu laporan, laporan penjualan, laporan penyewaan, laporan barang masuk, dan laporan barang keluar.

\section{E.1. Hasil Implementasi Sistem Backend Administrator}

Halaman administrator digunakan oleh administrator untuk melakukan aktifitas pengguna dalam fungsinya sebagai administrator. Pada saat pengguna berhasil login, maka akan ditampilkan halaman profil dari pengguna. Gambar 8 menunjukkan halaman pengelolaan tipe pengguna (administrator atau operator).

Menu kelola pengguna (Gambar 8 dan Gambar 9) digunakan oleh administrator untuk melakukan pengelolaan tipe pengguna baik untuk menambah, menghapus ataupun mengubah beserta hak akses yang diberikan.

\section{E.2. Hasil Implementasi Sistem Nursery Anggrek \\ E.2.1. Pengelolaan Data Master}

Pengelolaan data master terdiri dari pengelolaan data barang (Gambar 10), pengelolaan data rekanan (Gambar 11 dan Gambar 12), pengelolaan harga sewa (Gambar 13), dan pengelolaan harga beli.

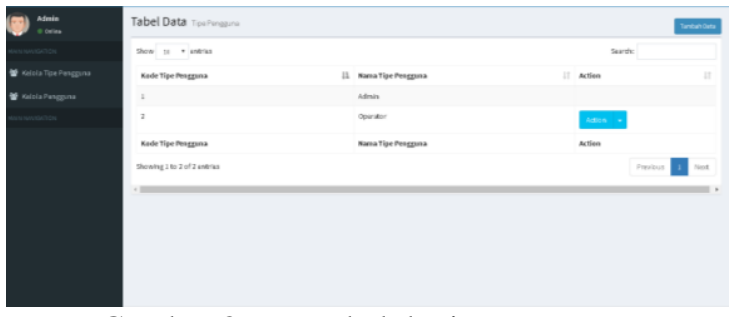

Gambar 8. Menu kelola tipe pengguna

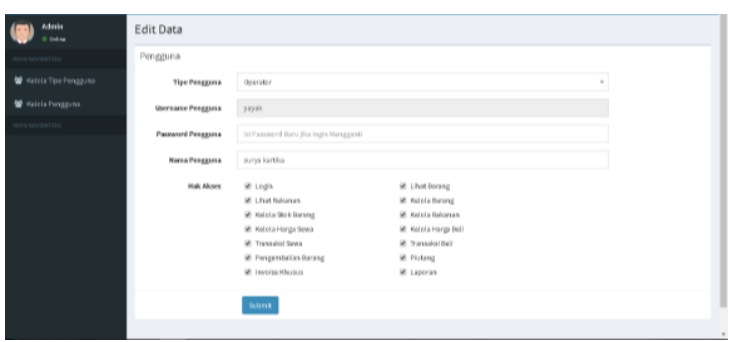

Gambar 9. Menu edit pengguna

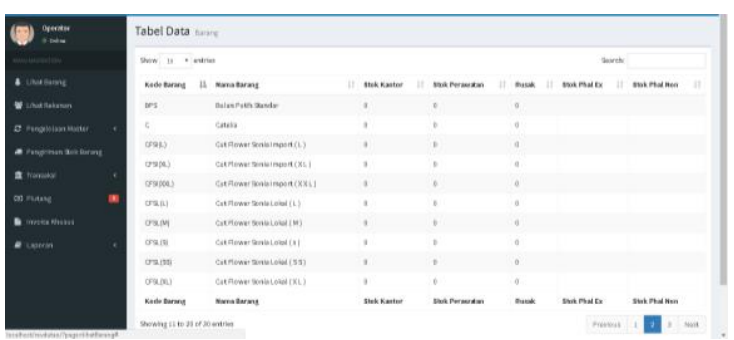

Gambar 10. Menu lihat barang

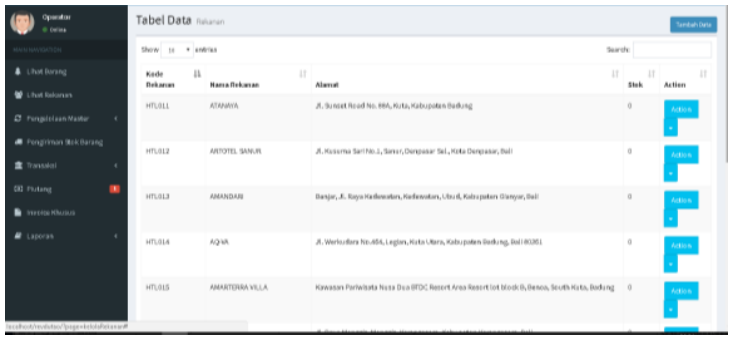

Gambar 11. Menu kelola rekanan

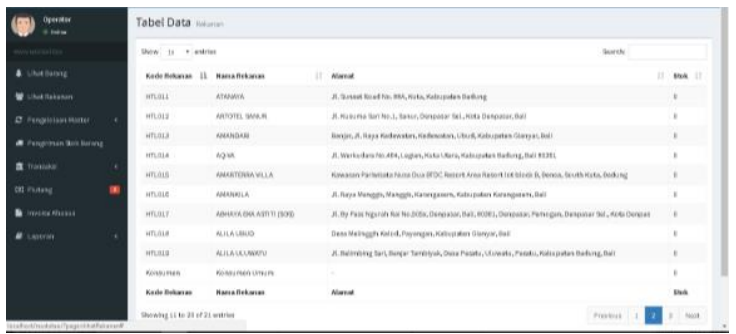

Gambar 12. Menu lihat rekanan

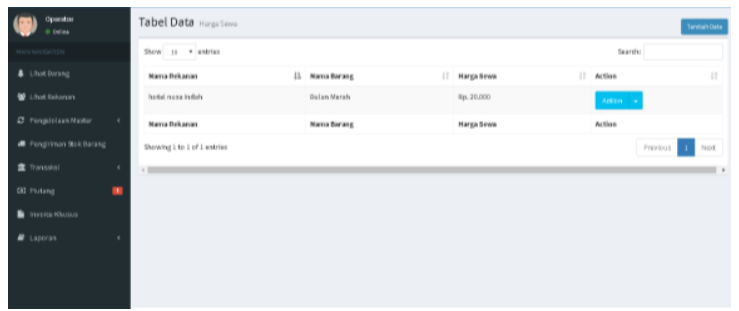

Gambar 13. Menu kelola harga sewa 


\section{E.2.2. Menu Pengiriman Stok Barang}

Menu pengiriman stok barang/bunga (Gambar 14) digunakan oleh pengguna untuk mengelola transaksi pengiriman barang stok baik dari supplier kekantor, dari kebun kekantor maupun dari kantor ke kebun.

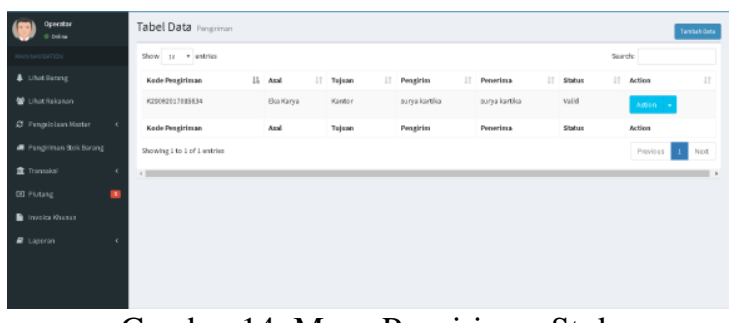

Gambar 14. Menu Pengiriman Stok

Dalam proses pengiriman barang, pengirim stok akan terisi otomatis sesuai dengan pengguna yang sedang menggunakan sistem. Proses penambahan transaksi pengiriman barang akan dilanjutkan dengan detail pengiriman barang (Gambar 15) dengan menambah barang-barang yang dikirim dan juga dapat dilakukan pencetakan tanda pengiriman barang (Gambar 16).

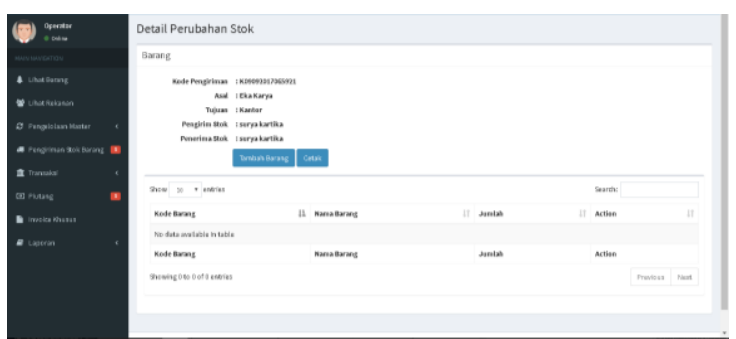

Gambar 15. Menu detail pengiriman barang

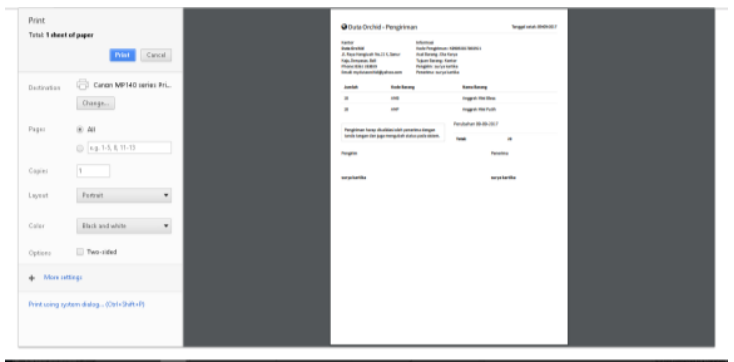

Gambar 16. Cetak surat kirim barang

Setelah membuat transaksi pengiriman barang, maka penerima barang harus melakukan validasi terhadap pengiriman yang dilakukan agar data masuk ke dalam stok dan transaksi dianggap sah. Penerima memiliki notifikasi dan jumlah notifikasi untuk transaksi pengiriman barang pada menu pengiriman stok barang.

\section{E.2.3. Menu transaksi}

Menu transaksi digunakan oleh pengguna untuk melakukan transaksi terhadap barang yang dimiliki. Menu transaksi memiliki beberapa submenu yaitu; transaksi sewa (Gambar 17), transaksii beli (Gambar 19 dan Gambar 20) dan pengembalian barang (Gambar 21). Transaksi sewa digunakan untuk penyewaan barang yang dilakukan oleh rekanan yang dimiliki. Transaksi beli digunakan untuk pembelian barang yang dilakukan oleh rekanan yang dimiliki. Harga sewa dan harga beli akan disesuaikan dengan harga sewa dan harga beli masing-masing rekanan yang telah dimasukkan pada pengelolaan master.

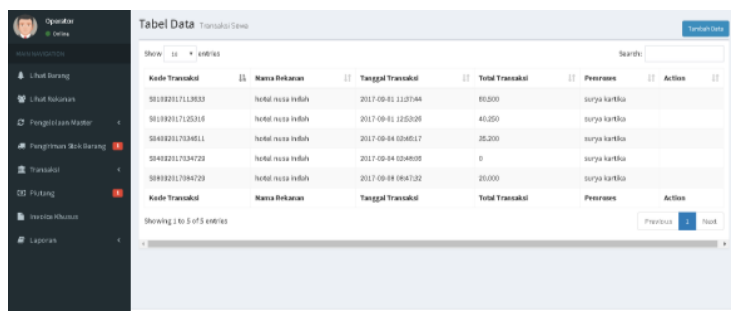

Gambar 17. Menu transaksi sewa

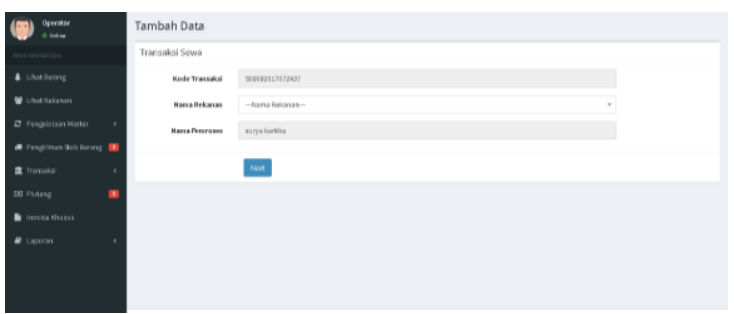

Gambar 18. Menu tambah transaksi sewa

Menu pada Gambar 18 digunakan oleh pengguna sistem untuk menambah transaksi sewa barang. Setelah pengguna memasukkan rekanan yang melakukan sewa, maka akan dilanjutkan dengan detail transaksi yang dilakukan untuk menambah barang, diskon, pajak, tanggal jatuh tempo pembayaran, pembayaran, mencetak tanda pengiriman barang dan juga mencetak invoice. Proses transaksi sewa tidak memerlukan validasi dari pengguna sistem lainnya. Pada saat menambah barang yang disewa, pengguna diminta untuk memasukkan data barang yang disewa, kondisi barang (normal, phal-ex, phal-non) dan juga jumlah yang disewa.
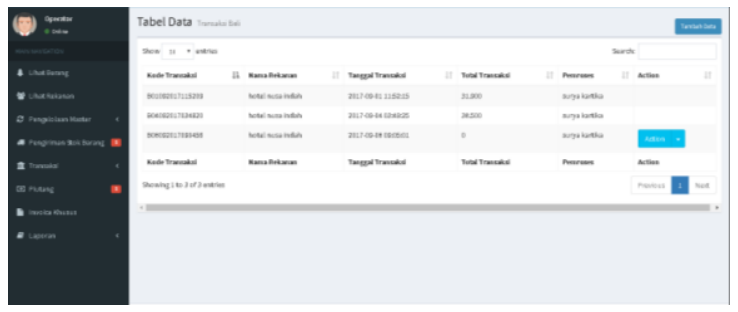

Gambar 19. Menu transaksi beli

Menu Gambar 19 dan Gambar 20 digunakan oleh pengguna untuk melakukan transaksi pembelian barang, proses transaksi beli tidak jauh berbeda dengan proses transaksi sewa. Transaksi beli dimulai dengan memasukkan data rekanan yang akan membeli barang, kemudian dilanjutkan dengan detail transaksi yang dilakukan untuk menambah barang, diskon, pajak, tanggal jatuh 
tempo pembayaran, pembayaran, mencetak tanda pengiriman barang dan juga mencetak invoice. Proses transaksi beli tidak memerlukan validasi dari pengguna sistem lainnya.

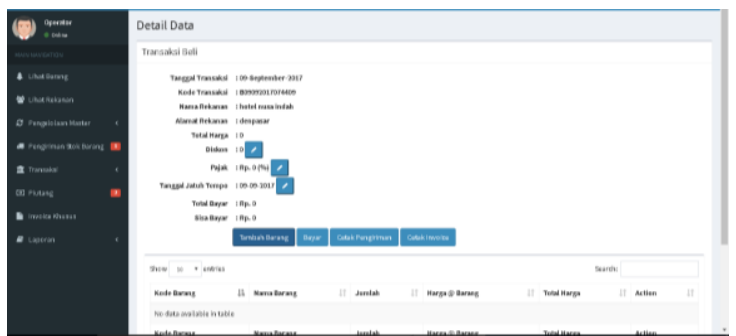

Gambar 20. Detail transaksi beli

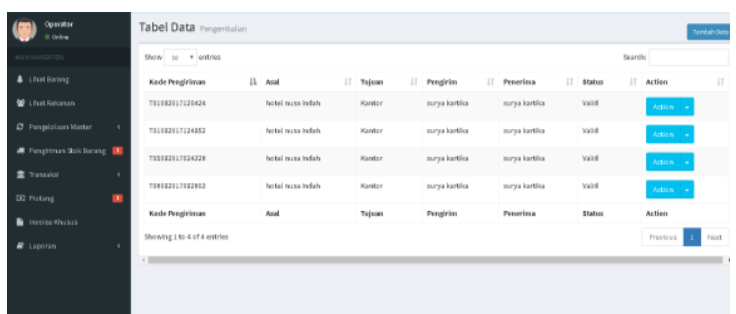

Gambar 21. Menu transaksi pengembalian

Menu Menu transaksi pengembalian digunakan oleh pengguna untuk melakukan transaksi pengembalian barang yang disewa oleh rekanan. Seluruh pengembalian barang akan masuk ke kantor dengan kondisi barang yang diterima.

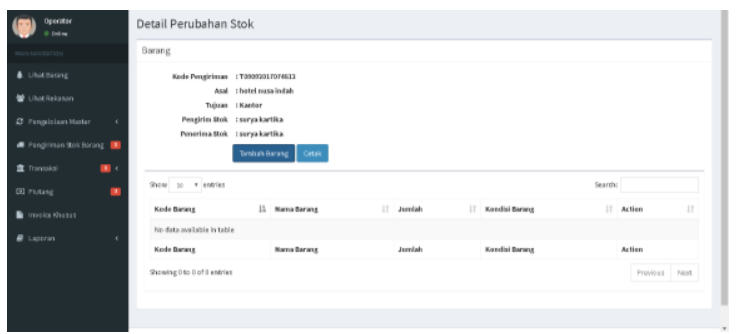

Gambar 22. Detail pengembalian barang

Menu Detail pengembalian barang (Gambar 22) digunakan oleh pengguna untuk menambah pengembalian barang. Proses yang harus dilakukan adalah dengan memasukkan data rekanan yang mengembalikan barang, kemudian dilanjutkan dengan detail pengembalian barang yang dilakukan. Selain itu juga diberikan menu untuk melakukan pencetakan tanda terima pengembalian barang. Setelah menambah transaksi pengembalian barang, maka diperlukan validasi untuk memastikan barang yang dikembalikan sesuai dengan dengan data yang dimasukkan.

\section{E.2.4. Menu Piutang}

Menu piutang ditunjukkan oleh Gambar 23. Menu ini digunakan oleh pengguna untuk melihat data piutang yang dimiliki dengan rekanan yang telah melakukan transaksi.

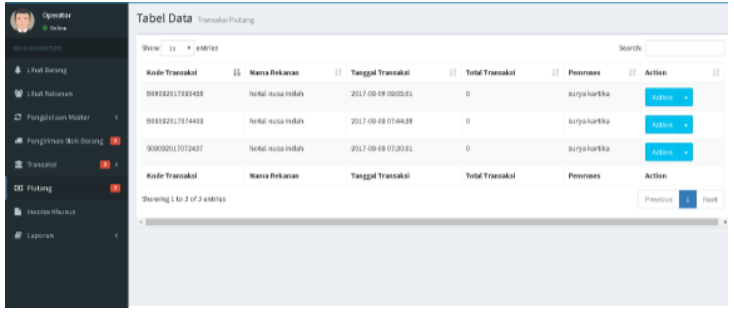

Gambar 23. Menu Transaksi Piutang

\section{E.2.5. Menu Laporan}

Menu ini terdiri dari penjualan (Gambar 24), penyewaan, barang masuk dan barang keluar. Menu ini digunakan oleh pengguna untuk melihat laporan transaksi penjualan, penyewaan, barang masuk dan barang keluar yang terjadi dalam waktu tertentu. Data tersebut ditambpilkan dalam bentuk grafik dan tabel data.

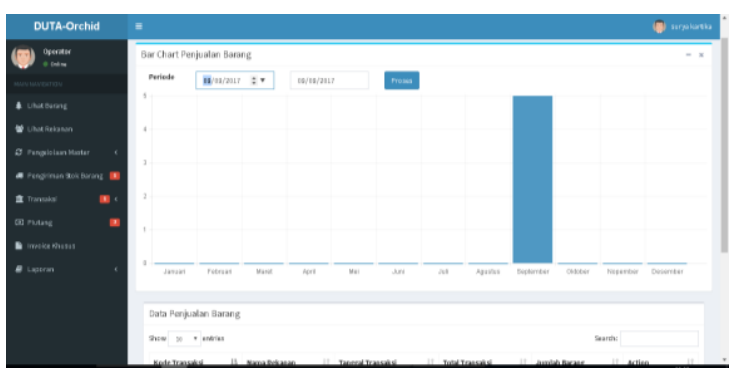

Gambar 24. Tampilan laporan

\section{E.3. Hasil Pengujian}

\section{E.3.1. Pengujian Unit}

Pengujian unit dilakukan dengan mengguna teknik blackbox. Hasil dari pengujian unit menunjukkan bahwa seluruh sistem menghasilkan hasil yang diharapkan [11]. Beberapa contoh hasil pengujian unit adalah ditunjukkan oleh Tabel 2.

Tabel 2. Contoh hasil pengujian unit

\begin{tabular}{lll}
\hline Unit & Kasus & Hasil \\
\hline Login & User operator & Login gagal. \\
& memasukkan & Username dan password \\
& username: xxx & tersebut belum tersimpan \\
& Password: yyy & Sistem Sukses \\
Kelola & User memasukkan & Data gagal tersimpan \\
Harga & data: & karena barang dengan \\
sewa & Nama rekanan: Hotel & nama Bug021 belum \\
& Bali 2 & tersimpan. \\
& Nama barang: Bug021 & Sistem Sukses \\
& Harga sewa: & \\
& 25000 & \\
Laporan & User memilih tanggal & Muncul tampilan data \\
penjualan & pelaporan 02 Juli & dalam bentuk grafik. \\
& 2018-03 Agustus 2018 & Sistem Sukses \\
\hline
\end{tabular}

\section{E.3.2. Pengujian Volume}

Kehandalan sistem dilakukan dengan mengunakan menguji tingkat ketahanan sistem terhadap data yang besar atau volume testing. Pada sistem Nursery Anggrek dilakukan penginputan data secara bertahap mulai dari 100, 500, 1500, 2500, dan $>4000$ data transaksi. Data transaksi tersebut diatur dalam kondisi piutang. Data dalam 
kondisi piutang dipilih untuk pengujian volume testing sebab kondisi tersebut menyebabkan relasi yang paling kompleks dibanding kondisi transaksi lunas atau yang lain dalam database.

Kategori kesuksesan sistem ditentukan dari waktu komputasi yang diperlukan untuk memproses data. Kategori tersebut dapat dilihat pada Tabel 3. Hasil pengujian dapat dilihat pada Tabel 4.

Tabel 3. Kategori kesuksesan

\begin{tabular}{ll}
\hline Waktu komputasi & Kesimpulan \\
\hline $0-5$ detik & Relevan \\
$5-15$ detik & Lambat \\
$>15$ detik & Sangat lambat \\
\hline
\end{tabular}

Tabel 4. Hasil pengujian volume

\begin{tabular}{|c|c|c|}
\hline $\begin{array}{l}\text { Jumlah } \\
\text { record data }\end{array}$ & \begin{tabular}{lrr} 
Waktu & \multicolumn{2}{c}{ komputasi } \\
untuk view & data \\
transaksi & &
\end{tabular} & Kesimpulan \\
\hline 100 & 1 detik 12 miliseconds & Relevan \\
\hline 500 & 1 detik 10 miliseconds & Relevan \\
\hline 1500 & 4 detik 58 miliseconds & Relevan \\
\hline 2500 & 9 detik 24 miliseconds & Lambat \\
\hline 4001 & 16 detik 45 miliseconds & $\begin{array}{l}\text { Sangat } \\
\text { lambat }\end{array}$ \\
\hline
\end{tabular}

Hasil dari pengujian volume menunjukkan bahwa sistem memerlukan waktu lebih dari 15 detik untuk memproses data dengan jumlah record 4000. Sistem masih relavan untuk digunakan dalam jumlah record data 0-1500 data. Semakin banyak waktu yang dibutuhkan untuk memproses data maka akan semakin memperberat kinerja prosesor komputer, serta penggunaan bandwidth menjadi lebih besar. Secara langsung hal tersebut akan menyebakan konsumsi listrik meningkat. Namun, hal tersebut masih akan dibuktikan melalui analisis sistem lanjutan.

\section{F. KESIMPULAN}

Berdasarkan hasil analisis, perancangan serta pengujian maka dapat disimpulkan, yaitu:

(1) Penelitian ini merupakan tahap pertama dari penelitian mengenai pengembangan perangkat lunak yang hijau mengadaptasi GREENSOFT Model.

(2) Hasil dari penelitian tahap pertama ini adalah sebuah sistem Nursery Anggrek yang memiliki fitur sesuai dengan kebutuhan fungsional pengguna. Kesesuaian terhadap kebutuhan non fungsional memerlukan pengujian lebih lanjut.

(3) Hasil pengujian unit menunjukkan bahwa seluruh unit beroperasi sesuai dengan ekspektasi dan kebutuhan pengguna.

(4) Sistem masih relavan untuk digunakan dalam jumlah record 0-1500 data. Semakin banyak waktu yang dibutuhkan untuk memproses data maka akan semakin memperberat kinerja prosesor komputer, serta penggunaan bandwidth menjadi lebih besar. Secara langsung hal tersebut akan menyebakan konsumsi listrik meningkat. Namun, hal tersebut masih akan dibuktikan melalui analisis sistem lanjutan.

\section{REFERENSI}

[1] Kartika, L. G. S., Pramana, G. A. B., \& Wibawa, I. P. A. A. S. (2017, August). Green computing survey based on user behavior: A case study in board of investment and licensing of Bali Province. In Cyber and IT Service Management (CITSM), 2017 5th International Conference on (pp. 1-6). IEEE.

[2] Naumann, S., Kern, E., Dick, M., \& Johann, T. (2015). Sustainable software engineering: Process and quality models, life cycle, and social aspects. In ICT Innovations for Sustainability (pp. 191205). Springer, Cham

[3] Penzenstadler B, Raturi A, Richardson D, Calero C, Femmer H, Franch X (2014) Systematic mapping study on software engineering for sustainability (SE4S). In: 18th International conference on evaluation and assessment in software engineering

[4] Koçak, S. A., Alptekin, G. I., \& Bener, A. B. (2015). Integrating Environmental Sustainability in Software Product Quality. In RE4SuSy@RE (pp. 17-24).

[5] Taina, J. (2011). Good, bad, and beautiful software-In search of green software quality factors. Cepis Upgrade, 12(4), 22-27.

[6] Kern, E., Dick, M., Naumann, S., Guldner, A., \& Johann, T. (2013). Green software and green software engineering-definitions, measurements, and quality aspects. Hilty et al.(2013), 87-94.

[7] Naumann, S., Dick, M., Kern, E., \& Johann, T. (2011). The greensoft model: A reference model for green and sustainable software and its engineering. Sustainable Computing: Informatics and Systems, 1(4), 294-304.

[8] Ericsson (2013) Ericsson energy, carbon report. On the impact of the networked society. EAB13:036469 Uen. Ericsson AB. http://www.ericsson.com/res/docs/2013/ericssonenergyand-carbon-report.pdf. diakses pada April 2014

[9] Mahmoud, S. S., \& Ahmad, I. (2013). A green model for sustainable software engineering. International Journal of Software Engineering and Its Applications, 7(4), 55-74.

[10] Taina, J. (2011). Good, bad, and beautiful software-In search of green software quality factors. Cepis Upgrade, 12(4), 22-27.

[11] Negara, I. K. R. Y. (2016). Implementasi si toni sebagai ujian berbasis komputer pada bisma informatika indonesia. Semnasteknomedia online, 4(1), 2-11. 